\title{
500 years of trophic-state history of a hypertrophic Dutch dike-breach lake
}

\author{
Emiliya P. Kirilova · Maarten van Hardenbroek • \\ Oliver Heiri · Holger Cremer · André F. Lotter
}

Received: 18 December 2008/Accepted: 14 August 2009/Published online: 29 August 2009

(C) The Author(s) 2009. This article is published with open access at Springerlink.com

\begin{abstract}
We present a palaeolimnological study encompassing five centuries of trophic-state change of the dike-breach lake De Waay located on the RhineMeuse delta (the Netherlands). Diatom-inferred total phosphorus (TP) concentrations indicate hypertrophic epilimnetic conditions $\left(>300 \mu \mathrm{g}^{-1} \mathrm{TP}\right)$ since the formation of the lake in the fifteenth century until the end of the eighteenth century. Cladocera data support the reconstructed trophic state and indicate turbid conditions in lake De Waay during this period. High inferred TP concentrations as well as the amount of Ti in the sediment reflect numerous flooding events. From the nineteenth century onwards reconstructed TP concentrations decreased to $40-150 \mu \mathrm{g} \mathrm{l}^{-1}$ due to improvements in sewage and dike systems that considerably diminished direct river flooding and seepage-derived nutrients. As a consequence, the increased stability of littoral habitats led to an increased diversity of the Cladocera assemblages.
\end{abstract}

E. P. Kirilova $(\bowtie) \cdot$ M. van Hardenbroek .

O. Heiri · A. F. Lotter

Palaeoecology, Institute of Environmental Biology,

Laboratory of Palaeobotany and Palynology, Utrecht

University, Budapestlaan 4, 3584 CD Utrecht,

The Netherlands

e-mail: e.p.kirilova@uu.nl

\section{H. Cremer}

Netherlands Organization for Applied Scientific Research TNO, Geological Survey of the Netherlands,

Princetonlaan 6, 3584 CB Utrecht, The Netherlands
The most significant decrease in TP concentrations to $\sim 40 \mu \mathrm{g}^{-1}$ occurred between about 1900 and 1930. This mesotrophic phase was a consequence of the isolation of the lake from catchment drainage and the introduction of a highly elaborate flood control during this period. However, since the mid twentieth century a eutrophication trend is preserved in the record, likely related to increased agricultural activity in the vicinity of the lake. Our results emphasize that landuse and trophic-state history must be taken into account when evaluating the ecological status of lakes for water management and protection actions, especially for lakes in landscapes that are strongly modified by human action.

Keywords Palaeolimnology · Eutrophication · Diatoms · Cladocera $\cdot$ Phosphorous reconstruction

\section{Introduction}

Cultural eutrophication has become a major environmental issue on a global scale (Smol 2008). Increased nutrient concentrations, irrespective of whether they are due to point or diffuse sources, can have adverse effects on ecosystem services and water quality. In lowland areas of Europe such as the Rhine-Meuse delta in the Netherlands, there is a long history of human impact and management of surface waters due to the need to control river systems in regions prone to flooding. It is therefore often unclear when nutrient 
concentrations started to increase in lakes and ponds in this region and how nutrient rich these waters were before the onset of the industrial period.

In the Netherlands, the effects of eutrophication of surface waters have been intensively studied (Van Dam and Buskens 1993). Ecological studies have illustrated a strong influence of factors such as human impact and climate on Dutch lakes, resulting in increased primary production and nutrient-enrichment (Mooij et al. 2005). Gulati and Van Donk (2002) discussed the interplay between the origin, eutrophication, and restoration of Dutch lakes, emphasizing the influence of rivers on the trophic state of lake ecosystems. Van der Molen and Portielje (1999) described the improvement of the nutrient status of many Dutch lakes as a result of decreased nutrient input and biomanipulation since the 1980s. However, there are still problems with the implementation of lake restoration programs as shown by Van Donk and Gulati (1995) for Lake Zwemlust, a lake that returned to its hypertrophic state 6 years after the onset of restoration. Historical records indicate that agricultural activities in the RhineMeuse drainage basin go back at least 7,500 years (Kalis et al. 2003). Bibus and Wesler (1995) showed that increased accumulation of flood deposits started during the Iron Age (800 BC), a process attributed to enhanced soil erosion due to increased agriculture. In the Middle Ages a new type of lake was formed due to dike breaches caused by high floods of the river Rhine. These dike-breach lakes have been strongly regulated by the development of a channel system and agriculture (Berendsen and Stouthamer 2001; Hudson et al. 2008). Despite several sedimentological, hydrological, and biological observations in the delta region (Lammens et al. 2008), the flooding history and ecology of these floodplain lakes have rarely been studied.

In order to assess how and when the ecological state of a lake changed, an understanding the lake's nutrient history is paramount. Palaeolimnological studies can help in understanding the long-term development of aquatic ecosystems and in defining natural baseline conditions (Bennion and Battarbee 2007). This is especially important in regions where legislature demands restoration measures based on undisturbed reference conditions, as they are defined in the European Water Framework Directive (WFD 2000).
Here we present a palaeolimnological study of the nutrient loading and ecology of De Waay, a Dutch dike-breach lake, based on fossil diatom and cladoceran assemblages preserved in the lake's sediment. We examine the present state of the lake in the context of its history, we address the effects of longterm intensive agriculture and irregular flooding, and we discuss how dike-breach lakes react to such disturbance events.

\section{Study site}

Lake De Waay is located in the central part of the Netherlands in an agricultural catchment, between the rivers Rhine and Linge in the lowest part of the Tielerwaard polder (Fig. 1). Lake De Waay is situated to the east of the Diefdijk, a secondary dike that prevents flooding of agricultural land in westerly polders and that prevents drainage of the easterly polder Tielerwaard. In the past this repeatedly resulted in prolonged flooding of the Tielerwaard polder and Lake De Waay after river dike breaches (Middelkoop 1997; van Hemmen et al. 2007; Hudson et al. 2008). The lake itself was formed in the fifteenth century by a dike breach of the Diefdijk, likely as a result of damage by floating ice in winter (van Hemmen et al. 2007). A scour hole of more than $27 \mathrm{~m}$ depth was created as the water in the large, flooded Tielerwaard polder drained through this breach.

Dike-breach lakes are common semi-natural lakes in the Dutch delta region. There are two main types of dike-breach lakes: outside the embankment and inside of the embankment. The lakes outside the embankment are flooded at every high-water stand of the river and their sediments mirror the seasonal river dynamics. In contrast, the lakes inside of the embankment are isolated from the direct river dynamics and are flooded after upstream dike breaches. Lake De Waay is located inside the embankment and documentary records show that this lake experienced more than 30 flooding events throughout its history (Teixeira de Mattos 1931; Gottschalk 1975, 1977; Bijl 2000). As the lake is located at the lowest part of the Tielerwaard polder, every dike breach within the polder will eventually result in a flooding of the site with river water. Lake De Waay thus provides an archive of dike breaches and flood events over several centuries, and because 
Fig. 1 Overview map of the Netherlands (a), bathymetry map of the lake basin (b), and detailed map of the location of Lake De Waay between the rivers Rhine and Linge (c)

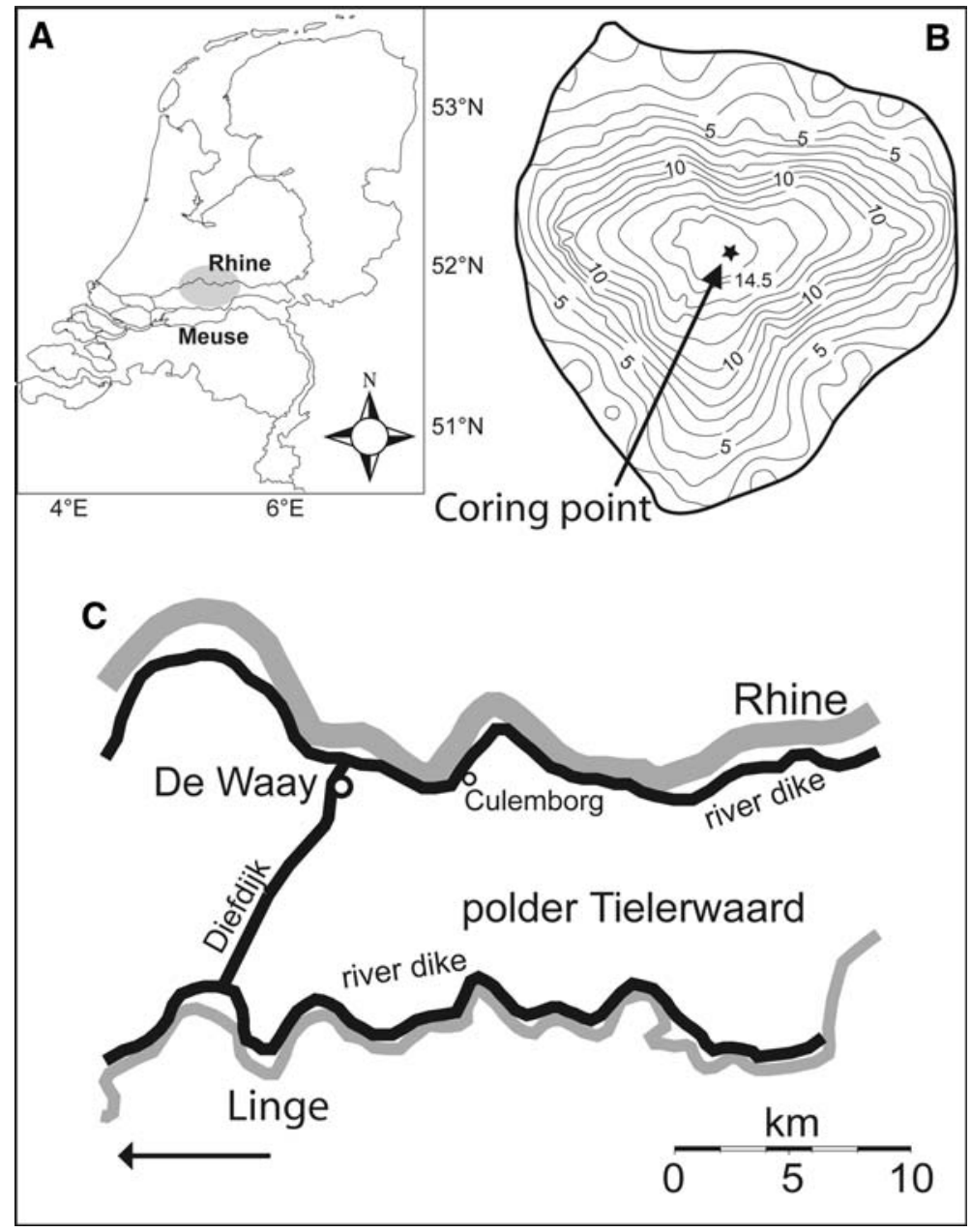

of its high sedimentation rate, it provides a sediment records with an exceptionally high temporal resolution. Moreover, it is the deepest dike-breach lake in the Netherlands $(15 \mathrm{~m}$ at present and $27 \mathrm{~m}$ at its origin), which reduces disturbance of sediments by wind. These features together with a gently sloping bathymetry that prevents sediment slumps make Lake De Waay an ideal site for palaeolimnological studies with regard to the reaction of floodplain lakes to different environmental stressors such as human impact on flooding.

Lake De Waay is a hypertrophic (total phosphorus $\sim 120 \mu \mathrm{g}^{-1}$ ) hardwater lake, with a maximum water depth of $15 \mathrm{~m}$ and a surface area of approximately 1.3 ha. It is a dimictic lake with a seasonally anoxic hypolimnion, high concentrations of hypolimnetic $\mathrm{H}_{2} \mathrm{~S}$, and a thermocline, which develops in April between 5 and $6 \mathrm{~m}$ water depth.

\section{Materials and methods}

Chronology

A total of 29 sediment samples were used for gamma spectrometric determination of ${ }^{137} \mathrm{Cs}$ activity performed at the University of Waterloo Environmental Change Research Laboratory. In addition, two samples (kiril_WAY-899, terrestrial coleopteran; kiril_WAY-6128, wood) were Accelerator Mass Spectrometry (AMS) radiocarbon dated at the Van de Graaff Laboratorium, Utrecht University.

Sediment coring

After a bathymetric survey with an echo sounder in 2005 (Fig. 1), a complete sediment sequence was recovered from Lake De Waay at a water depth of 
$14.5 \mathrm{~m}$ using a piston corer (UWITEC, Austria) with a drive of $300 \mathrm{~cm}$. Undisturbed top sediments were collected with a UWITEC gravity corer. Overlapping sediment sections were collected until the base of the lake sediments was reached, as indicated by the occurrence of distinct sand lenses. The core segments were cut into $100-\mathrm{cm}$ sections, split in half, photographed, and the overlapping cores were stratigraphically correlated using visual marker horizonts, XRF data, and lithological characteristics. This resulted in a continuous 1,152-cm long composite sediment sequence that was sampled in the laboratory at contiguous $1-\mathrm{cm}$ intervals.

\section{Geochemistry}

The freshly split and cleaned core segments were scanned with an Avaatech $^{\circledR}$ XFR core scanner (Richter et al. 2006) at the Royal Netherlands Institute for Sea Research (NIOZ). Al, Si, K, Ca, $\mathrm{Ti}, \mathrm{Mn}$, and $\mathrm{Fe}$ were measured at contiguous $1-\mathrm{cm}$ resolution throughout the whole sediment sequence. Ti showed the highest predictive power in a principal components analysis and was used as a proxy for allochtonous minerogenic input (Haberzettl et al. 2007). Loss-on-ignition (LOI) analyses were carried out in 10-cm intervals for every core section following Heiri et al. (2001).

\section{Diatom analysis}

Fifty-nine sediment samples were freeze dried and a known weight of dry sediment was processed for diatom analysis following Battarbee (1973). Slides were prepared by the sedimentation tray method (Battarbee 1973) and using Naphrax ${ }^{\circledR}$ as mounting medium. Between 223 and 500 diatom valves were counted per slide at $1,000 \times$ magnification using an Olympus BX51 microscope. For diatom identification and taxonomy Krammer and Lange-Bertalot (1991a, 1999a, b, 2000), and Håkansson (2002) were used.

Diatom assemblage zones were defined by optimal sum of squares partitioning (Birks and Gordon 1985) using the program ZONE (Lotter and Juggins 1991). The statistically significant number of zones was assessed by the broken stick model (Bennett 1996). The lowermost four samples between 1,152 and $1,100 \mathrm{~cm}$ were excluded from the interpretations as their diatom counts were extremely low.
Cladocera

Twenty-one volumetric samples of $0.02-0.072 \mathrm{ml}$ fresh sediment were taken at approximately $50-\mathrm{cm}$ intervals for Cladocera analysis and prepared following Korhola and Rautio (2001). Quantitative slides were made by pipetting $0.02 \mathrm{ml}$ of the well-stirred sample onto a slide, covered with a $20 \times 20 \mathrm{~mm}$ cover slip, and sealed with nail polish. Slides were examined at 100-1,000 $\times$ magnification using a light microscope identifying approximately 150 remains in each sample using the keys by Frey (1958, 1959), Korinek (1971), Amoros (1984), and Dodson and Frey (1991).

Diatom-inferred total phosphorus reconstruction

Total phosphorus (TP) concentrations were estimated by weighted averaging partial least squares (WA-PLS) regression and calibration (ter Braak et al. 1993; ter Braak and Juggins 1993) using the software C2 (version 1.5, Juggins 2007). The diatomTP model was developed from a set of 429 lakes from a combined diatom-TP data-base consisting of the EDDI (http://craticula.ncl.ac.uk/Eddi/jsp/) and the Mecklenburg-Vorpommern calibration dataset (Adler and Hübener 2007; http://www.biologie.uni-rostock. de/abt/botanik/AG-Phykologie/). The sites were selected on the basis of similar species composition and comparable limnological parameters such $\mathrm{pH}$, alkalinity, and TP. The TP concentrations in the modern diatom training set range from 2 to $1,189 \mu \mathrm{g} 1^{-1}$. For the calibration and regression of the WA-PLS model diatom percentages were squareroot transformed and TP was log transformed. The performance of the inference model was assessed using leave-one-out cross-validation and has root mean square error of prediction (RMSEP) of $0.28 \mathrm{log}$ TP units and a coefficient of determination $\left(r^{2}\right)$ of 0.73 .

\section{Diversity estimates}

We applied rarefaction analysis (Heck et al. 1975) using the program RAREPOLL (Birks and Line 1992) to infer changes in the taxonomic diversity of diatom assemblages in the sediments of Lake De Waay, and we standardized the analysis to the lowest number of diatoms counted (223 valves). 


\section{Results}

\section{Chronology}

In the ${ }^{137} \mathrm{Cs}$ profile, the $\mathrm{AD} 1986$ peak representing the Chernobyl incident is clearly seen at $20.5 \mathrm{~cm}$ sediment depth and the AD 1963 bomb test peak appears at $38.5 \mathrm{~cm}$ depth. The first detectable ${ }^{137} \mathrm{Cs}$ activity representing $\mathrm{AD} 1954$ is registered at $52.5 \mathrm{~cm}$ depth (Fig. 2). ${ }^{210} \mathrm{~Pb}$ activities were measured but only very low activities were registered due to dilution in the rapidly accumulating sediments.

The oldest radiocarbon sample gave a date of $778 \pm 62 \mathrm{cal}$. BP $(1,051 \mathrm{~cm})$. This age, however, would predate the formation of the lake. Before the fifteenth century, Diefdijk was only a shallow levee and a dike breach that could have formed the lake would have been impossible. We therefore assume that this sample likely consists of reworked material that was washed into Lake De Waay during a flooding event. After the fifteenth century, the Diefdijk was raised to provide better protection against flooding, and it is only after this date that the conditions were favorable for formation of a dike-

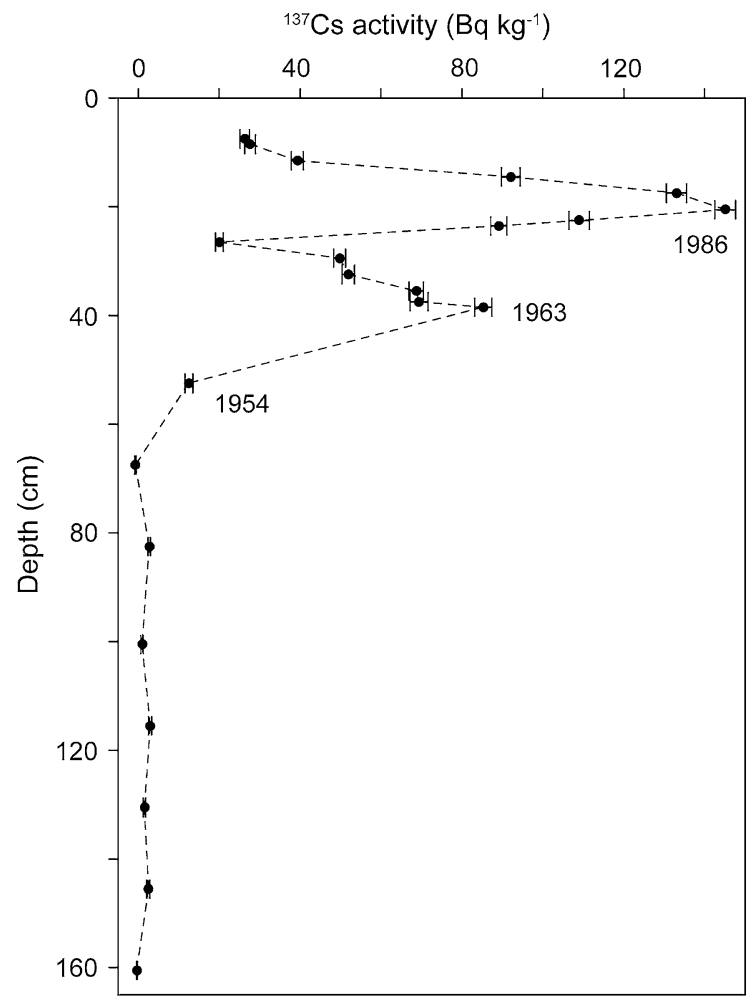

Fig. $2{ }^{137} \mathrm{Cs}$ dating of Lake De Waay sediments breach lake. We assume that the younger radiocarbon date of $393 \pm 20 \mathrm{cal}$. BP $(560 \mathrm{~cm})$ in the middle of the sediment sequence was based upon reworked wood that was introduced by river flooding, and therefore it is also too old. As a consequence, the ${ }^{14} \mathrm{C}$ dates cannot be used as reliable absolute dates.

Based on historical records, the lake was created in AD 1496 due to a dike breach (van Hemmen et al. 2007) and we, therefore, take this as the basal age for our record. The age-depth model used in this study is based on a linear interpolation between the core top, the ${ }^{137} \mathrm{Cs}$ dates, and the historical basal date.

\section{Diatoms}

The diatoms show three statistically significant assemblage zones (D1-3; Fig. 3). The first zone (D1: $1,100-650 \mathrm{~cm}$ ) is characterized by the dominance of the planktonic diatom Stephanodiscus hantzschii Grunow (in Cleve and Grunow) typical for hypertrophic lakes (Anderson and Odgaard 1994), which infrequently alternated with Cyclostephanos dubius (Fricke) Round in Theriot et al. another eutrophic indicator (Van Dam et al. 1994). During the second assemblage zone (D2: 650-220 cm), the abundance of $S$. hantzschii declined and $C$. dubius and Aulacoseira granulata (Ehrenberg) Simonsen became the dominant species. In addition, Puncticulata bodanica (Grunow in Schneider) Håkansson, Puncticulata radiosa (Lemmermann) Håkansson, and Cyclotella ocellata Pantocsek occurred in this zone, taxa which typically indicate meso- to oligotrophic lakes (Kling and Håkansson 1988). In the third zone (D3: $220-0 \mathrm{~cm}$ ), the diatom assemblages show a more complex succession with two main groups of diatoms becoming important. The interval $220-170 \mathrm{~cm}$ is dominated by $P$. bodanica and $P$. radiosa, whereas $S$. hantzschii is the dominant diatom in the interval $170-150 \mathrm{~cm}$. Between 150 and $70 \mathrm{~cm}$, the diatom assemblages are dominated by $P$. bodanica and $P$. radiosa, whereas $S$. hantzschii dominates again the youngest part of the lake's history. Asterionella formosa Hassall and Stephanodiscus medius Håkansson also frequently occurred in the upper $2 \mathrm{~m}$ of the core.

\section{Cladocera}

Throughout the entire core, planktonic Bosminidae were the most dominant group, representing approximately 


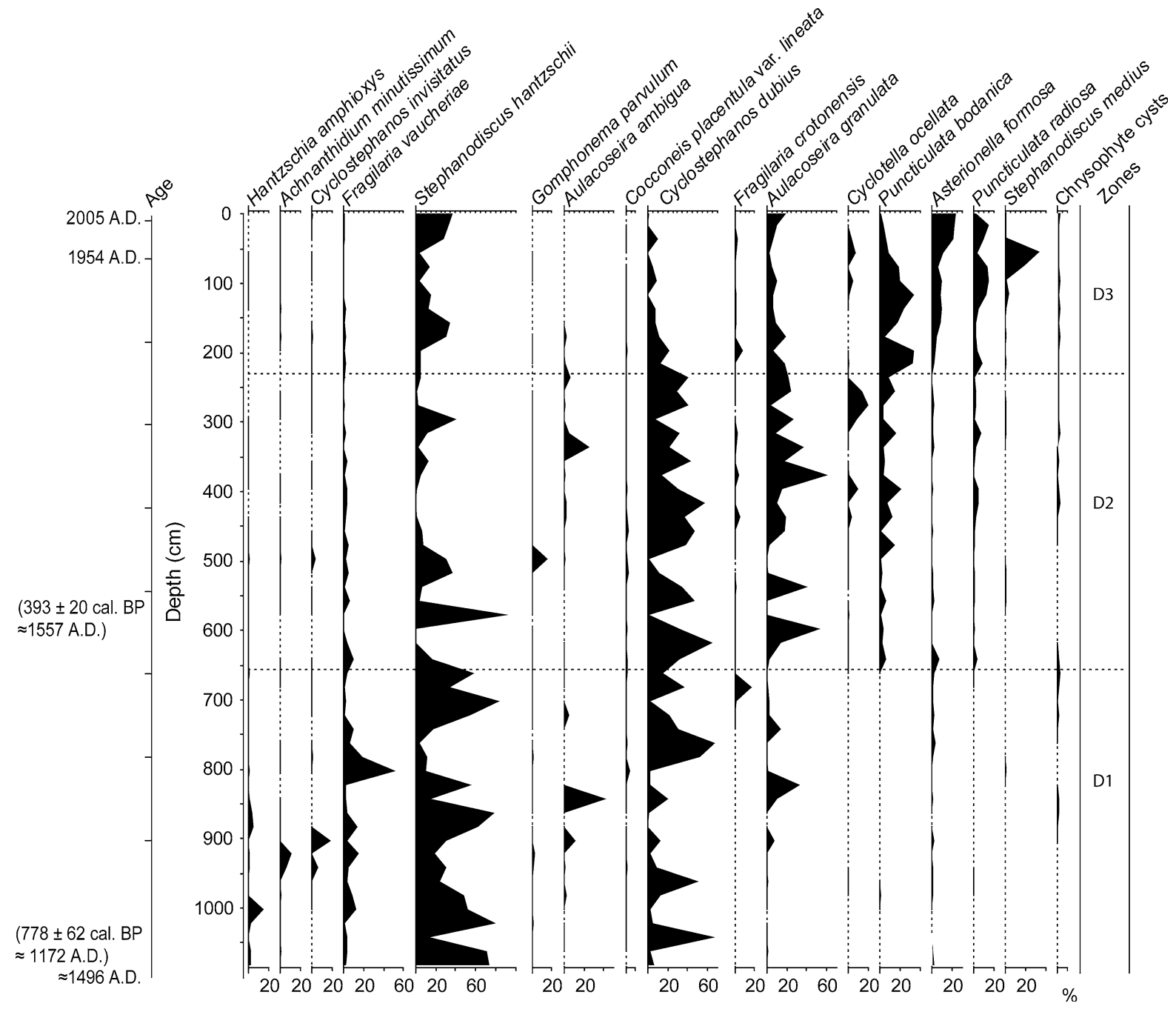

Fig. 3 Diatom assemblages and chrysophyte cysts in the sediment sequence from Lake De Waay. Values are given as percentages of total diatoms counted. Rejected ${ }^{14} \mathrm{C}$ dates are indicated in brackets

$80 \%$ of the total Cladocera (Fig. 4). Although up to half of these could only be identified as Bosmina spp., Daphnia occurs in very low abundances in the sediment from $470 \mathrm{~cm}$ upwards.

Based on the benthic Cladocera, three assemblage zones $(\mathrm{C} 1-3)$ are differentiated. The first zone $(\mathrm{C} 1$ : $1,100-830 \mathrm{~cm})$ is characterized by the dominance of Chydorus sphaericus. It is found within all lentic systems, but often in lakes with higher nutrient concentrations (Brodersen et al. 1998). Throughout the sequence other species like Alona rectangula and A. quadrangularis, which are abundant in eutrophic lakes (Whiteside 1970; Brodersen et al. 1998), remain present as well as species such as Campocercus rectirostris and Alonella nana found in oligo- to mesotrophic waters (Brodersen et al. 1998). A diversification of the cladoceran fauna occurs in the second zone $(\mathrm{C} 2: 830-570 \mathrm{~cm})$ where Peracantha truncata first occurs, a cladoceran that tends to indicate eutrophic conditions (Brodersen et al. 1998). Together with P. truncata we also found Graptoleberis testudinaria and Alona costata, both typical for mesotrophic habitats (Whiteside 1970; Brodersen et al. 1998) and Alona guttata, which is an indicator of oligotrophic waters. Also, the predator Leptodora kindti first occured in this zone. The increase in the 


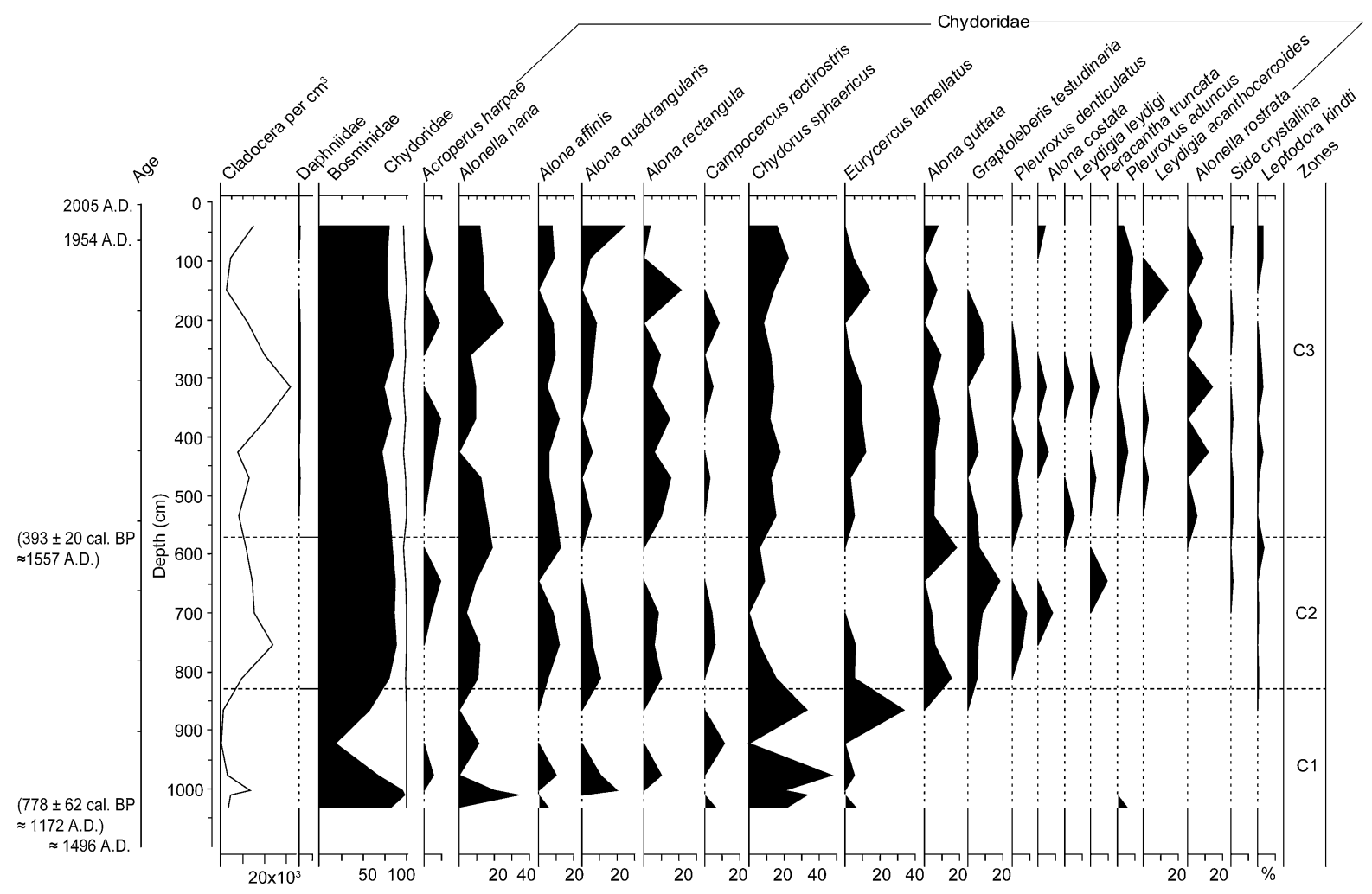

Fig. 4 Cladocera assemblages in the sediment core from Lake De Waay. Values are given as percentages of total Cladocera counted. Rejected ${ }^{14} \mathrm{C}$ dates are indicated in brackets

number of taxa goes together with a decline in percentages of $C$. sphaericus. At approximately $570 \mathrm{~cm}$, another change marks the onset of the third zone (C3: $570 \mathrm{~cm}$ - present), during which C. sphaericus and $A$. rectangula become more abundant again. In this zone Pleuroxus aduncus, Leydigia leydigi, and L. acanthocercoides are found in Lake De Waay, indicating eutrophic conditions (Whiteside 1970; Brodersen et al. 1998). Several chydorid species (not shown in Fig. 4) occur sporadically during this zone with highest numbers of cladoceran taxa between 570 and $230 \mathrm{~cm}$.

\section{Geochemistry}

We use $\mathrm{Ti}$ as indicator for allochtonous minerogenic input (Mayr et al. 2007), with high Ti values representing possible flooding events or other disturbances (e.g., repairing of the dike) in the catchment of the lake. High counts of $\mathrm{Ti}$ were registered from the bottom of the core at 1,100 to $70 \mathrm{~cm}$ below the sediment/water interface, whereas in the top $70 \mathrm{~cm}$ the Ti values decreased (Fig. 5).

The organic matter content is stable around $15 \%$ dry weight from the bottom of the sequence $(1,100 \mathrm{~cm})$ to $175 \mathrm{~cm}$. Between 175 and $150 \mathrm{~cm}$ it dropped sharply by about $8 \%$ and from $150 \mathrm{~cm}$ to the top of the core it increased again, stabilizing at approximately $19 \%$.

\section{Diatom-inferred TP reconstruction}

Between the end of the Middle Ages and the onset of the nineteenth century $(1,100-430 \mathrm{~cm})$ diatom-inferred TP concentrations show a gradually decreasing trend from 300 to about $90 \mu \mathrm{g} \mathrm{TP} 1^{-1}$ (Fig. 5). During the nineteenth century $(430-150 \mathrm{~cm})$ the values fluctuated between about 150 and $40 \mu \mathrm{g} \mathrm{TP} 1^{-1}$. The lowest concentrations of $30-40 \mu \mathrm{g} \mathrm{TP} 1^{-1}$ were inferred at the beginning of the twentieth century and lasted about 30 years $(150-70 \mathrm{~cm})$, just before TP increased again to $70-120 \mu \mathrm{g}^{-1}$ during the past 70 years. 


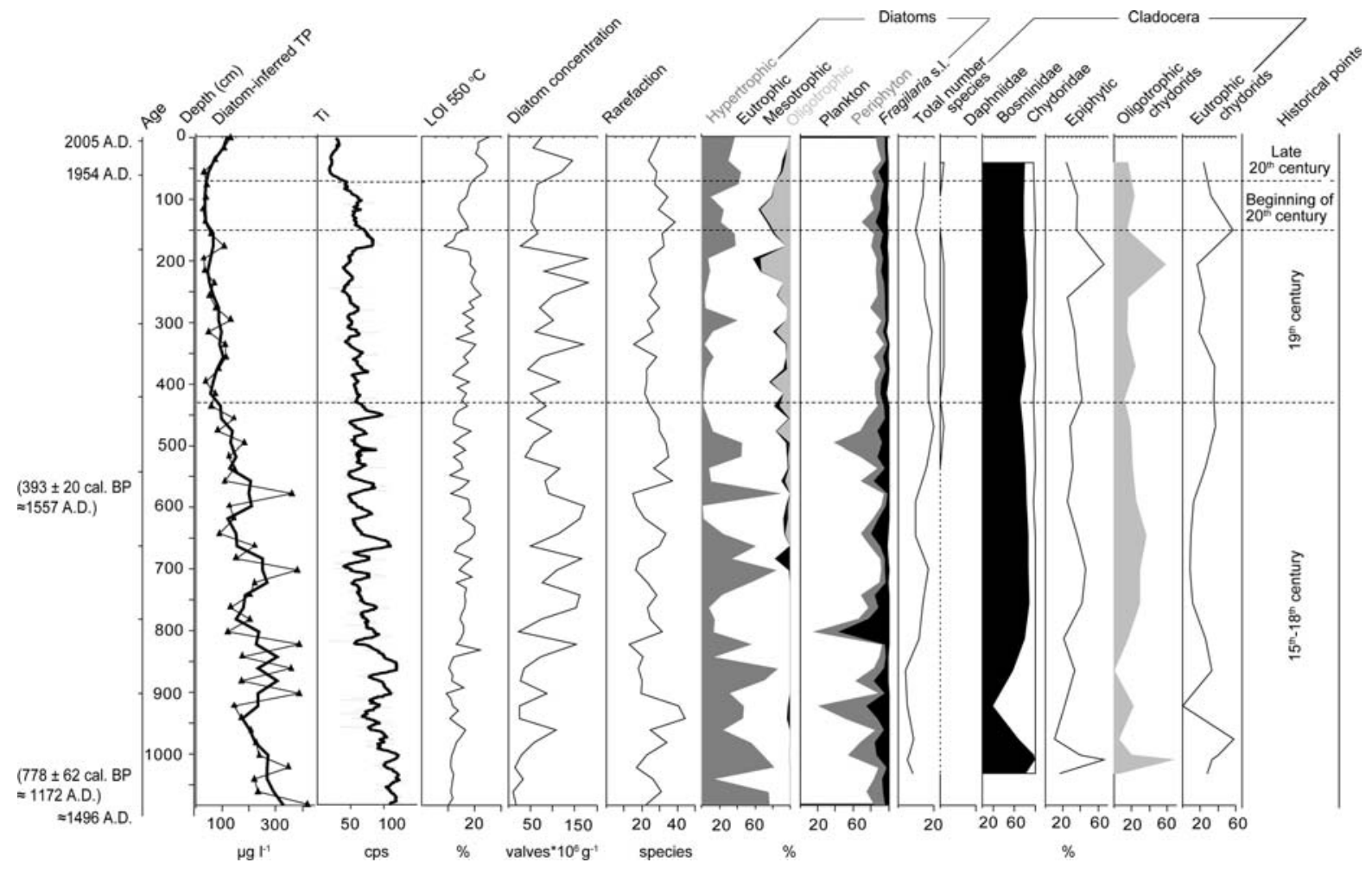

Fig. 5 Diatoms (Van Dam et al. 1994) and cladocerans (Brodersen et al. 1998) grouped according to trophic and habitat preferences, LOI, rarefaction of diatom assemblages, and diatom-inferred total phosphorus (TP) for the sediment

\section{Discussion}

The dating of the sediment record from Lake De Waay is excellent for the uppermost part of the sediment sequence $(0-55 \mathrm{~cm})$. Beyond the range of caesium dating, the available records have been plotted on an age scale by linearly interpolating between the oldest ${ }^{137} \mathrm{Cs}$ date and the bottom of the sediment sequence, which is assumed to represent deposits laid down soon after the formation of the lake in AD 1496. Both radiocarbon ages obtained for the record have been rejected since they are apparently too old considering historical information on the formation of the lake. This older organic material was most likely transported into the lake during one of a number of flooding events affecting the polder and lake between the fifteenth and the eighteenth century (Teixeira de Mattos 1931; Gottschalk 1975, 1977; Bijl 2000). Lakes may experience abrupt changes in sedimentation rates even in periods with record from Lake De Waay. Rejected ${ }^{14} \mathrm{C}$ dates are indicated in brackets. The age-scale indicates the approximate age of the sediments based on interpolation between ${ }^{137} \mathrm{Cs}$ dates and the basal age (AD 1496) based on historical records

comparatively minor changes in climatic conditions or human activity (Heiri et al. 2003), potentially causing errors in age-depth relationships based on interpolations between dates widely separated in time. Nevertheless, the available age-constraints in the present study allow the discussion of the lake's development on an approximate age scale. Based on this chronology, we identify four major phases in the lake's history (Fig. 5).

Hypertrophic phase (fifteenth to eighteenth century)

Inferred TP concentrations in the lowermost section of the record were above $300 \mu \mathrm{g} \mathrm{l}^{-1}$ (Fig. 5), which suggests hypertrophic conditions at the beginning of Lake De Waay's existence in the fifteenth century $(1,100 \mathrm{~cm})$. The occurrence of $S$. hantzschii (abundances up to 80\%) and Cyclostephanos dubius (up to $65 \%$ ) (Fig. 3) are indicative of hypertrophic 
conditions. Historical evidence indicates that the lake has been used as part of a large drainage system (van Hemmen et al. 2007). Three canals (Redichemmer wetering, Goilberdinger wetering and Nieuwe wetering) came together at the location of De Waay already since early thirteenth century. From that location the water was made to go South in the canal Culemborgse Vliet to pump the water away towards river Linge. Nutrients from extended areas of surrounding agricultural land were therefore potentially washed into the lake. Moreover, the waste water of the nearby town of Culemborg, which attained city status in $\mathrm{AD} 1318$, was directly discharged into the lake via a channel (B. Blommers, pers. commun.). The absence or the very low concentrations of chrysophyte cysts indicates a low $\mathrm{Si}: \mathrm{P}$ ratio (Smol 1985) and enriched phosphorus concentrations, and this supports the TP estimate. Besides the nutrient enrichment from the catchmen, the inferred high TP concentrations may also partially be attributed to internal phosphorus loading due to sediment nutrient release under anoxic conditions.

Until the late eighteenth century $(1,100-400 \mathrm{~cm})$ floods were common in the area (Gottschalk 1975, 1977). The elevated Ti values (Fig. 5) indicate high erosional input (Mayr et al. 2007) most likely from the river floodplain and runoff from the surrounding agricultural catchment, causing the rapid infilling (Hudson et al. 2008) of the lake basin with exceptionally high sedimentation rates of $\sim 2.3 \mathrm{~cm}_{\text {year }}{ }^{-1}$. In addition to the high sedimentation rates, the lake exhibits fluctuating diatom concentrations and abrupt changes in the dominant hypertrophic diatom taxa (Fig. 5). Hantzschia amphioxis (Ehrenberg) Grunow in Cleve and Grunow is a terrestrial diatom (van Kerckvoorde et al. 2000), and the elevated percentage in the lowest part of the record points to soil input due to regular flooding of the area (Fig. 3). Elevated and fluctuating concentrations of periphytic diatoms were observed, and this was likely caused by frequent flooding that resulted in disturbances of the littoral zone and its macrophytes (Horner et al. 1990). In addition, high percentages of Fragilaria spp. likely indicate turbid periods (Denys 1990). At Lake De Waay, high abundances of this genus in the lower sections of the sediment sequence may have been favored by regular flooding of the lake and its environments.

These dynamic hydrological conditions in Lake De Waay are also reflected in the Cladocera assemblages, especially until the mid-eighteenth century. Whiteside (1970) described Cladocera assemblages similar to the ones encountered in our study as representing a lake's pioneer stage, probably lacking rooted aquatic macrophytes as a result of low water transparency. At Lake De Waay frequent floods may have caused such a low transparency in the early years (Fig. 4) and may even have washed away submerged and floating-leaved macrophytes, important for the development of a diverse cladoceran assemblage (Whiteside 1970). High abundances of Chydorus sphaericus and the occurrence of Alona rectangula and Alona quadrangularis indicate eutrophic or 'polluted' conditions (Brodersen et al. 1998) until the seventeenth century $(1,100-830 \mathrm{~cm})$. Then, in the seventeenth and eighteenth centuries $(830-570 \mathrm{~cm})$, Chydorus sphaericus became less abundant and Graptoleberis testudinaria and Alona guttata increased, indicating a gradual shift towards meso- to oligotrophic conditions (Whiteside 1970; Brodersen et al. 1998) and thus confirming the decrease in diatom-inferred TP values (Figs. 3, 5). Factors such as the frequency and amplitude of catastrophic disturbance (Goulden 1969) similar to flood events in De Waay, habitat availability (Whiteside 1970), and food supply (Kerfoot et al. 1988) may also have had a strong influence on the cladoceran communities. It is therefore conceivable that flooding and elevated nutrient conditions in the lake influenced cladoceran communities indirectly. However, fish predation may have had a more important effect on cladocerans communities. Throughout the core, extremely low abundances of Daphnia spp. have been encountered in contrast to the high abundances of Bosmina spp. Size-selective predation by fish commonly leads to the replacement of large Daphnia spp. by small Bosmina spp. (Kitchell and Kitchell 1980). Observations made in the 1970s indicate that the lake was (and still is) populated by white fish (bream, roach) as well as predatory fish (pike, perch, ruffe), carp, and eel. Carp were observed several times during fieldwork in 2005-2008. Based on the low Daphnia spp. abundances throughout the sediment record, it can be assumed that predatory fish were present in the lake since its creation.

Eutrophic phase (nineteenth century)

Since the second half of the eighteenth century (approximately $700 \mathrm{~cm}$ ) the amount of sewage input 
and the flooding frequency affecting Lake De Waay were strongly reduced by the construction of new ditches, canals, and dikes (Bijl 2000; van Hemmen et al. 2007; B. Blommers, pers. commun.). Around 1750 the Nieuwe Dike was created (now called Sonsbrug) with a canal along it that cut off lake De Waay from most of the drainage water. These changes are apparent in the Ti curve which is more stable than in the older sections of the sediment core, suggesting reduced erosive input into the lake (Fig. 5). Percentages of hypertrophic diatoms decreased and taxa such as Cyclostephanos dubius and Aulacoseira granulata, which are typical for eutrophic conditions, became dominant, reaching abundances up to 30 and $60 \%$, respectively. In addition, limnetic TP concentrations varied between 40 and $150 \mu \mathrm{g} \mathrm{l}^{-1}$, suggesting large fluctuations in the nutrient input (Fig. 5). However, the overall trend was towards a decrease in the TP concentrations. At the end of this stage Puncticulata bodanica, a diatom with oligo- to mesotrophic affinities (Kling 1997), was abundant (up to 20\%), suggesting a reduction in nutrients (Fig. 3).

From the second half of the eighteenth to the nineteenth century $(570-230 \mathrm{~cm})$, an increase in the number of benthic cladoceran taxa is observed (Fig. 5). The majority of the chydorid species that occurred during this period live among floatingleaved or submerged macrophytes or dwell between debris at the lake bottom (Goulden 1964; Whiteside 1970; Amoros 1984). Similar increases in cladoceran diversity with pioneer species such as Chydorus sphaericus, Alona affinis, Acroperus harpae, Alona quadrangularis, and Alonella nana were observed in lakes of northern Europe during deglaciation when a more diverse macrophyte vegetation developed (Goulden 1964; Whiteside 1970; Hofmann 2001). Decreasing flood frequency also allows a larger number of species to develop in a lake (Frey 1988). The trend towards lower $\mathrm{Ti}$ values since the eighteenth century is interpreted as a decrease in floodinduced sediment deposition. This is corroborated by historical evidence indicating a reduction of flooding events that affected Lake De Waay in the nineteenth and early twentieth centuries (Bijl 2000; van Hemmen et al. 2007). The highest numbers of cladoceran taxa are found in the nineteenth and twentieth century when Lake De Waay was less influenced by floods.

Chydorus sphaericus and Pleuroxus aduncus, two chydorids typical for eutrophic conditions, increase slightly in the nineteenth and twentieth centuries, whereas cladocerans indicating oligotrophic waters did not decrease. We suggest that these shifts in the cladoceran community are likely the effect of changes in habitat availability and catchment stability rather than a direct consequence of decreasing $\mathrm{TP}$ values since the nineteenth century.

Mesotrophic phase (beginning twentieth century)

The phase with the lowest inferred TP conditions lasted from the end of the nineteenth to the midtwentieth century $(150-70 \mathrm{~cm})$. At this time, nutrient sources like canals from the nearby town of Culemborg were no longer connected to the lake (B. Blommers, pers. commun.) and TP concentrations consequently decreased. The dike construction was highly developed and flooding events no longer affected this region (Gottschalk 1975, 1977). The high $\mathrm{Ti}$ counts can be explained by the intensive strengthening and repairing of the dike at the beginning of twentieth century (Teixeira de Mattos 1931; Bijl 2000). Puncticulata bodanica, which is indicative of oligo- to mesotrophic conditions, increased up to $40 \%$, whereas low percentages of diatoms with eutrophic and hypertrophic affinities were observed (Fig. 5). Due to reduced nutrient influxes, the nutrient concentrations in Lake De Waay decreased. Diatoms suggest TP values of $\sim 40 \mu \mathrm{g}^{-1}$ indicating mesotrophic waters. The cladoceran fauna does not show any clear indication of further oligotrophication during this period. The eutrophic species Chydorus sphaericus and Alona quadrangularis increase slightly, but oligotrophic species like Alonella nana and Alona gutatta also remain present. As argued above, this is likely to reflect changes in habitat availability rather than changes in nutrient levels.

Re-eutrophication phase (mid-twentieth century to today)

Since the mid-twentieth century, diatom-inferred TP concentrations have shown an increasing trend to up to $\sim 100 \mu \mathrm{g} \mathrm{l}^{-1}$. The process of oligotrophication stopped and the percentages of diatom taxa typical of low nutrient loading decreased considerably to less than $2 \%$ (Fig. 5). The renewed eutrophication reflects increased fertilizer use in agriculture. Anderson 
(1997) observed a comparable situation in Northern Ireland, where increases in TP concentrations were caused by enhanced field drainage and animal waste disposal. During this phase, the lowest Ti values were observed (Fig. 5), indicating that the input of minerogenic matter originating from floods did not affect the lake anymore.

In contrast to the first phase of the lake development when diatoms with hypertrophic affinities were dominating, the diatom assemblages in the uppermost sediment layers indicate less eutrophic nutrient conditions. Hence, the occurrence of oligo- and mesotrophic diatoms in substantial abundances points to a better ecological state compared to the assemblages deposited during the high Middle Ages just after the formation of the lake.

Diversity and nutrient regulation in floodplain lakes

Lake De Waay has been a nutrient-rich lake throughout its entire, geologically short history as evidenced by its diatom and cladoceran assemblages as well as by the inferred TP concentrations (Fig. 5). Floods and water regulation as well as internal loading are the major causes of the high nutrient status to the lake. During the period with enhanced flooding, Stephanodiscus hantzschii was present at high percentages indicating elevated nutrient concentrations (Fig. 3). Both diatom and cladoceran diversity increased slightly over the past last 150 years, likely due to a decrease in both flooding frequency and TP concentrations, the former leading to stabilization of the littoral zone and increased habitat availability for benthic and periphytic organisms (Figs. 3, 4, 5).

The history of Lake De Waay emphasizes several issues related to water management in general and to the European Water Framework Directive in particular. Lake De Waay can be classified as a deep floodplain lake, highly influenced by human activity, both through land use and water management. Since its creation, the lake has always been hydrologically dependent on the regulation of the rivers Rhine and Linge and on the management of the surrounding agricultural land. This inherent link between lake, catchment, and river must be considered when assessing the ecological state of such a floodplain lake (Vannote et al. 1980).
Phosphorous levels dropped considerably in Lake De Waay as the lake became increasingly isolated from its wider catchment by a more intensive water management. It is only during the last century that very stable hydrological conditions have been established through drainage and river management, resulting in a considerable reduction of the flooding frequency. Consequently, the frequency of disturbance and eventually the TP concentrations have decreased, whereas biodiversity and lake-shore stability have increased (Van der Brink et al. 1994). Such management measures in the catchment are significantly different from the situation in high medieval times. As a consequence of the low level of medieval water management, the hydrology and ecology of the lake was greatly affected by the disturbance frequency and the extent of flooding.

Lake De Waay is presently a hypertrophic system and has been subject to a distinct increase in nutrient concentrations since the 1950s. However, our results also indicate that the lake was eutrophic to hypertrophic during much of its existence. Similarly, the lake's nutrient level has always been strongly affected by human activities such as agriculture, hydrological management, and drainage of the polder landscape. The approach of viewing the ecological status of lakes in the context to their "undisturbed" natural state, as is the approach used in the European Water Framework Directive (Bennion and Battarbee 2007; Kirilova et al. 2009), therefore might not be adequate when applied to Lake De Waay. The lake was formed as a consequence of dike building in a highly dynamic floodplain landscape, and it never existed in an "undisturbed" state. Depending on the time scale considered, its present state can be viewed as nutrient enriched with regard to the past 100 years or even as nutrient depleted if compared with its state during the fifteenth-eighteenth centuries. Hence, our results indicate that for lakes formed by human activity, such as dike-breach lakes, detailed information on past land use and trophic state is essential for defining appropriate reference conditions and restoration goals in the context of their history.

Acknowledgments We would like to thank Ton van Druten and Nina Bonis for their help obtaining the sediment cores. Dr. H. Middelkoop, Dr. E. Stouthamer, and Dr. W. Hoek are acknowledged for discussing suitable sites and their sedimentology. We are grateful to Dr. Kaarina SarmajaKorjonen for the help indentifying Cladocera species. Wim 
Gutte kindly provided information about the occurrence of fish in De Waay and Bert Blommers provided us with historical information about the study area. Johan Wiklund performed radiometric dating using gamma spectroscopy. We would like to acknowledge Adam Ehrat for the linguistic comments on the paper. This research has been supported by Utrecht Center of Geosciences and the Center for Wetland Ecology. This is Netherlands Research School of Sedimentary Geology (NSG) contribution no. 20090801.

Open Access This article is distributed under the terms of the Creative Commons Attribution Noncommercial License which permits any noncommercial use, distribution, and reproduction in any medium, provided the original author(s) and source are credited.

\section{References}

Adler S, Hübener T (2007) Spatial variability of diatom assemblages in surface lake sediments and its implications for transfer functions. J Paleolimnol 37:573-590

Amoros C (1984) Introduction pratique à la systématique des organismes des eaux continentales françaises-5. Crustacés, Cladocères, Bulletin de la Société Linnéenne de Lyon 53:72-107 and 120-144

Anderson NJ (1997) Reconstructing historical phosphorus concentrations in rural lakes using diatom models. In: Tunney H, Carton OT, Brookes PC, Johnston AE (eds) Phosphorus loss from soil to water. Proceedings of an international workshop, CAB International, pp 95-118

Anderson NJ, Odgaard BV (1994) Recent palaeolimnology of three shallow Danish lakes. Hydrobiologia 275(276): 411-422

Battarbee RW (1973) A new method for estimation of absolute microfossil numbers, with reference especially to diatoms. Limnol Oceanogr 18:647-653

Bennett KD (1996) Determination of the number of zones in a biostratigraphical sequence. N Phytol 132:155-170

Bennion H, Battarbee RW (2007) The European Union water framework directive: opportunities for palaeolimnology. J Paleolimnol 38:285-295

Berendsen HJA, Stouthamer E (2001) Palaeogeographic development of the Rhine-Meuse delta, The Netherlands. Koninkijke Van Gorcum, Assen, The Netherlands pp 268

Bibus E, Wesler J (1995) The middle Neckar as an example of fluviomorphological processes during the Middle and Late Quaternary Period. Zeitschrift für Geomorphologie N. F. Supplement Band 100:15-26

Bijl A (2000) Tussen de Diefdijk en de Zouwedijk, een Waterstaatkundige en Sociaal-Economische Geschiedenis van de Vijfheerenlanden (1566-1984). De Groot Drukkerij B.V., Goudriaan

Birks HJB, Gordon AD (1985) Numerical methods in quaternary pollen analysis. Academic Press, London

Birks HJB, Line JM (1992) The use of rarefaction analysis for estimating palynological richness from Quaternary pollenanalytical data. Holocene 2:1-10

Brodersen KP, Whiteside MC, Lindegaard C (1998) Reconstruction of trophic state in Danish lakes using subfossil chydorid (Cladocera) assemblages. Can J Fish Aquat Sci 55:1093-1103

Denys L (1990) Fragilaria blooms in the Holocene of the western coastal plain of Belgia. In: Simola H (ed) Proceedings of the tenth international diatom symposium, Joensuu, Finland, 28th August-2nd September 1988. Koeltz Scientific Books, Koenigstein, pp 397-406

Dodson SI, Frey DG (1991) Cladocera and other branchiopoda. In: Thorpe JHAPC (ed) Ecology and classification of North American freshwater invertebrates. Academic Press Inc., Toronto, pp 723-786

European Union (2000) Directive 2000/60/EC of the European Parliament and of the Council of 23 October 2000 on establishing a framework for community action in the field of water policy. J Eur Commun L327:1-72

Frey DG (1958) The late-glacial cladoceran fauna of a small lake. Arch Hydrobiol 54:209-275

Frey DG (1959) The taxonomic and phyolgenetic significance of the head pores of the genus Chydoridae (Cladocera). Int Rev Gesamten Hydrobiol 44:27-50

Frey DG (1988) Littoral and offshore communities of diatoms, cladocerans and dipterous larvae, and their interpretation in paleolimnology. J Paleolimnol 1:179-191

Gottschalk MKE (1975) Stormvloeden en Rivieroverstomingen in Nederland. Deel 2: de Periode 1400-1600. van Gorcum, Assen

Gottschalk MKE (1977) Stormvloeden en Rivieroverstomingen in Nederland. Deel 3: de Periode 1600-1700. van Gorcum, Assen

Goulden CE (1964) The history of the cladoceran fauna of Esthwaite Water (England) and its limnological significance. Arch Hydrobiol 60:1-52

Goulden CE (1969) Temporal changes in diversity. In: Woodwell GM, Smith HH (eds) Diversity and stability in ecological systems. Brookhaven symposium in Biology, vol 22, pp 96-102

Gulati RD, van Donk E (2002) Lakes in the Netherlands, their origin, eutrophication and restoration: state of the art review. Hydrobiologia 478:73-106

Haberzettl T, Corbella H, Fey M, Janssen S, Lücke A, Mayr C, Ohlendorf C, Schäbitz F, Schleser GH, Wille M, Wulf S, Zolitschka B (2007) Lateglacial and Holocene wet-dry cycles in southern Patagonia: chronology, sedimentology and geochemistry of a lacustrine record from Laguna Potrok Aike, Argentina. Holocene 17: 297-310

Håkansson H (2002) A compilation and evolution of species in the genera Stephanodiscus, Cyclostephanos and Cyclotella with a new genus in the family Stephanodiscaceae. Diatom Res 17:1-139

Heck KL, Van Belle G, Simberloff DS (1975) Explicit calculation of the rarefaction diversity measurement and the determination of sufficient sample size. Ecology 56: 1459-1461

Heiri O, Lotter AF, Lemcke G (2001) Loss on ignition as a method for estimating organic and carbonate content in sediments: reproducibility and comparability of results. J Paleolimnol 25:101-110

Heiri O, Wick L, van Leeuwen JFN, van der Knaap WO, Lotter AF (2003) Holocene tree immigration and the chironomid fauna of a small Swiss subalpine lake (Hinterburgsee, 
$1515 \mathrm{~m}$ asl). Palaeogeogr Palaeoclimatol Palaeoecol 189:35-53

Hofmann W (2001) Late-glacial/holocene succession of the chironomid and cladoceran fauna of the Soppensee (Central Switzerland). J Paleolimnol 25:411-420

Horner RR, Welch EB, Seeley MR, Jacoby JM (1990) Responses of periphyton to changes in current velocity, suspended sediment and phosphorus concentration. Freshw Biol 24:215-232

Hudson PF, Middelkoop H, Stouthamer E (2008) Flood management along the Lower Mississippi and Rhine Rivers (The Netherlands) and the continuum of geomorphic adjustment. Geomorphology 101:209-236

Juggins S (2007) C2 Version 1.5 User guide. Software for ecological and palaeoecological data analysis and visualization. Newcastle University, Newcastle upon Tyne, UK, p 69

Kalis AJ, Merkt J, Wunderlich J (2003) Environmental changes during the Holocene climatic optimum in central Europe human impact and natural causes. Q Sci Rev 22:33-79

Kerfoot WC, Levitan C, DeMott WR (1988) Daphnia-phytoplankton interactions: density-dependent shifts in resource quality. Ecology 69:1806-1825

Kirilova E, Heiri O, Enters D, Cremer H, Lotter AF, Zolitschka B, Hübener T (2009) Climate-induced changes in the trophic status of a Central European lake. J Limnol 68: 71-82

Kitchell JA, Kitchell JF (1980) Size-selective predation, light transmission and oxygen stratification: evidence from recent sediments of manipulated lakes. Limnol Oceanogr 25:389-403

Kling HJ (1997) Ecology, ontogeny, and morphology of the freshwater centric diatom species complex: Cyclotella bodanica/radiosa. Master thesis, Department of Botany, University of Manitoba, Winnipeg Manitoba, pp 263

Kling H, Håkansson H (1988) A light and electron microscopy study of Cyclotella species (Bacillariophyceae) from central and northern Canadian lakes. Diatom Res 3:55-82

Korhola A, Rautio M (2001) Cladocera and other branchiopod crustaceans. In: Smol JP, Birks HJB, Last WM (eds) Tracking environmental change using lake sediments. Zoological indicators, vol 4. Kluwer, Dordrecht, pp 5-41

Korinek V (1971) Comparative study of head pores in the genus Bosmina BAIRD (Crustacae, Cladocera). Vestnik Ceskoslovenske Spolecnosti Zoologicke 35:275-296

Krammer K, Lange-Bertalot H (1991) Bacillariophyceae 4. Teil: achnanthaceae. In: Ettl H, Gärtner G, Gerloff J, Heynig H, Mollenhauer D (eds) Süßwasserflora von Mitteleuropa, Band 2/4. Gustav Fischer Verlag, Heidelberg, p 437

Krammer K, Lange-Bertalot H (1999a) Bacillariophyceae 1. Teil: naviculaceae. In: Ettl H, Gerloff J, Heynig H, Mollenhauer D (eds) Süßwasserflora von Mitteleuropa, Band 2/1. Gustav Fischer Verlag, Heidelberg, p 876

Krammer K, Lange-Bertalot H (1999b) Bacillariophyceae 2. Teil: bacillariaceae, epithemiaceae, surirellaceae. In: Ettl H, Gerloff J, Heynig H, Mollenhauer D (eds) Süßwasserflora von Mitteleuropa, Band 2/2. Gustav Fischer Verlag, Heidelberg, p 611

Krammer K, Lange-Bertalot H (2000) Bacillariophyceae 3. Teil: centrales, fragilariaceae, eunotiaceae. In: Ettl $\mathrm{H}$,
Gärtner G, Gerloff J, Heynig H, Mollenhauer D (eds) Süßwasserflora von Mitteleuropa, Band 2/3. Gustav Fischer Verlag, Heidelberg, p 599

Lammens E, Van Luijn F, Wessels Y, Bouwhuis H, Noordhuis R, Portielje R, Molen DVD (2008) Towards ecological goals for the heavily modified lakes in the IJsselmeer area, The Netherlands. Hydrobiologia 599:239-247

Lotter AF, Juggins S (1991) POLPROF, TRAN and ZONE: programs for plotting, editing and zoning pollen and diatom data. Inqua-subcommission for the study of the Holocene, working group on data-handling methods. Newsletter 6:4-6

Mayr C, Wille M, Haberzettl T, Fey M, Janssen S, Lücke A, Markgraf V, Ohlendorf C, Oliva G, Schäbitz F, Schleser G-H, Zolitschka B (2007) Holocene variability of the southern hemisphere westerlies in Argentinean Patagonia $\left(52^{\circ} \mathrm{S}\right)$. Q Sci Rev 26:579-584

Middelkoop H (1997) Embanked floodplains in the Netherlands, geomorphological evolution over various time scales. PhD Thesis, University Utrecht

Mooij WM, Hülsmann S, De Senerpont Domis LN, Nolet BA, Bodelier PLE, Boers PCM, Dionisio Pires ML, Gons HJ, Ibelings BW, Noordhuis R, Portielje R, Wolfstein K, Lammens EHRR (2005) The impact of climate change on lakes in the Netherlands: a review. Aquat Ecol 39: $381-400$

Richter TO, van der Gaast S, Koster B, Vaars A, Gieles R, de Stigter HC, De Haas H, van Weering TCE (2006) The Avaatech XRF Core Scanner: technical description and applications to NE Atlantic sediments. In: Rothwell RG (ed) New techniques in sediment core analysis. Geological Society, London, Special Publications, vol 267, pp 39-50

Smol JP (1985) The ratio of diatom frustules to chrysophycean statospores: a useful paleolimnological index. Hydrobiologia 123:199-208

Smol JP (2008) Pollution of Lake and Rivers: a paleoenvironmental perspective, 2nd edn. Blackwell Publishing, Oxford

Teixeira de Mattos LF (1931) De Waterkeeringen, Waterschappen en Polders van Zuid-Holland, part IV-3. Martinus Nijhoff, Den Haag, pp 810-830

Ter Braak CJF, Juggins S (1993) Weighted averaging partial least squares regression (WA-PLS): an improved method for reconstructing environmental variables from species assemblages. Hydrobiologia 269(270):485-502

Ter Braak CJF, Juggins S, Birks HJB, van der Voet H (1993) Weighted averaging partial least squares regression (WA-PLS): definition and comparison with other methods for species-environment calibration. In: Rao CR (ed) Multivariate environmental statistics. North-Holland, Amsterdam Chapter 25 in GP Patil

Van Dam H, Buskens RFM (1993) Ecology and management of moorland pools: balancing acidification and eutrophication. Hydrobiologia 265:225-263

Van Dam H, Mertens A, Sikeldam J (1994) A coded checklist and ecological indicator values of freshwater diatoms from the Netherlands. Neth J Aquat Ecol 28:117-133

Van der Brink FWB, Van Katwijk MM, Velde GVD (1994) Impact of hydrology on phyto- and zooplankton community composition in floodplain lakes along the Lower Rhine and Meuse. J Plankton Res 16:351-373 
Van der Molen DT, Portielje R (1999) Multi-lake studies in the Netherlands: trends in eutrophication. Hydrobiologia 408(409):359-365

Van Donk E, Gulati RD (1995) Transition of a lake to turbid state six years after biomanipulation: mechanisms and pathways. Water Sci Technol 32:197-206

Van Hemmen F, Bekius D, Heunks E (2007) Schone slaperHollands hoop in bange dagen, cultuurhistorisch advies voor de verbetering van de 'Diefdijklinie'. In: RAAPreport 1531, RAAP Archeologisch Adviesbureau B.V., Amsterdam
Van Kerckvoorde A, Trappeniers K, Nijs I, Beyens L (2000) Terrestrial soil diatom assemblages from different vegetation types in Zackenberg (Northeast Greenland). Polar Biol 23:392-400

Vannote RL, Minshall GW, Cummins KW, Sedell JR, Cushing CE (1980) The river continuum concept. Can J Fish Aquat Sci 37:130-137

Whiteside MC (1970) Danish chydorid cladocera. Ecol Monogr 40:79-118 